\title{
Carbonylation of nickel and selectively reduced laterite ore
}

\author{
by Y. Cui, G. Zhang, S. Jahanshahi, and 0. Ostrovski
}

\section{Synopsis}

Carbonylation of nickel obtained by reduction of nickel oxide and selectively reduced Australian laterite ore was studied at temperatures of $80-100^{\circ} \mathrm{C}$ and CO gauge pressures of 0-56 atm. The effects of sulphur-containing catalysts on the nickel carbonylation were also examined. The results show that the extent of nickel carbonylation increased with increasing temperature from 80 to $100^{\circ} \mathrm{C}$ at constant CO pressure. The carbonylation of nickel at $100^{\circ} \mathrm{C}$ and $\mathrm{CO}$ gauge pressure $27 \mathrm{~atm}$. was close to completion after 5.5 hours of reaction. At all temperatures, the effect of CO pressure was very strong when the gauge pressure was increased from zero to $14 \mathrm{~atm}$. Sulphurcontaining catalysts accelerated the carbonylation reaction. The time for complete carbonylation of nickel was reduced from 5.5 hours in the noncatalytic reaction to 2 hours in the catalytic carbonylation at $100^{\circ} \mathrm{C}$ and co gauge pressure $14 \mathrm{~atm}$. The extent of carbonylation of nickel from the selectively reduced laterite ore with particle size $53-200 \mu \mathrm{m}$ at $100^{\circ} \mathrm{C}$ and CO gauge pressure $41 \mathrm{~atm}$. was below $50 \%$. The use of catalysts in the carbonylation of selectively reduced ore was ineffective. The rate of reaction increased with decreasing particle size and increasing gas flow rate.

Keywords

nickel, laterite ore, carbonylation, selective reduction.

\section{Introduction}

The major source of nickel is sulphide ores, which have a relatively high nickel content and can be easily upgraded by beneficiation. However, depletion of sulphide deposits and increasing demand for nickel has led to the increasing utilization of laterite ores. Laterite ores cannot be efficiently upgraded by physical means, which leads to significant challenges in the extraction of nickel.

Nickel carbonylation is broadly used for refining of nickel produced by the pyrometallurgical processing of laterite ore (Vale, 2017). Nickel and iron form carbonyls, which are separated by distillation. Terekhov and Emmanuel (2013) studied the reduction of limonite and saprolite ores at $650^{\circ} \mathrm{C}$ followed by carbonylation of nickel and iron by $\mathrm{CO}$ at $180^{\circ} \mathrm{C}$ and $60 \mathrm{~atm}$. pressure. The extraction of Ni from limonite ore (48 hours' reaction time) was above $92 \%$. Extraction of Ni from saprolite ore was faster; reaching $95.6 \%$ in 18 hours (Terekhov and Emmanuel, 2013)

This paper presents the results of a study of carbonylation of nickel produced by reduction of $\mathrm{NiO}$ and nickel from selectively reduced laterite ore. The aim is to examine the feasibility of the alternative technology for the extraction of nickel from laterite ore by selective reduction followed by carbonylation.

\section{Experimental}

Carbonylation of pure nickel and nickel in selectively reduced laterite ore was studied at temperatures of $80-100^{\circ} \mathrm{C}$ and $\mathrm{CO}$ gauge pressures of 0-56 atm. Nickel was produced by reduction of NiO by hydrogen at $500^{\circ} \mathrm{C}$. Laterite ore was selectively reduced using a $\mathrm{CO}-\mathrm{CO}_{2}$ gas mixture containing 60 vol. $\% \mathrm{CO}$ at $750^{\circ} \mathrm{C}$. Reduction experiments were conducted in a horizontal furnace (Ceramic Engineering, Sydney, Australia).

Carbonylation experiments were conducted in a flexible U-shaped reactor (max. pressure $68 \mathrm{~atm}$.) immersed in an oil bath. The schematic set-up for the carbonylation experiments is shown in Figure 1.

The reaction temperature was controlled by the oil bath. The outlet gas flow rate was adjusted by a needle valve and monitored by a gas flow meter. Pressure was regulated by the valve regulator. Carbonyls were absorbed using three Dreschel bottles filled with aqua regia. A fourth absorption bottle, filled with 20 $w t \%$ sodium hydroxide solution, was used to treat the corrosive chlorine gas from the Dreschel bottles.

Samples were placed in the reactor, which was immersed in the oil bath and connected to the gas system. To reduce oxides that could be formed on the surface of the reduced samples, the samples were heated to $150^{\circ} \mathrm{C}$ in hydrogen for 2 hours. When the oil bath reached the

* School of Materials Science and Engineering, University of New South Wales, Sydney, Australia.

(c) The Southern African Institute of Mining and Metallurgy, 2018. ISSN 2225-6253. This paper was first presented at the INFACON XV: International Ferro-Alloys Congress, 25-28 February 2018, Century City Conference Centre and Hotel, Cape Town, South Africa 


\section{Carbonylation of nickel and selectively reduced laterite ore}

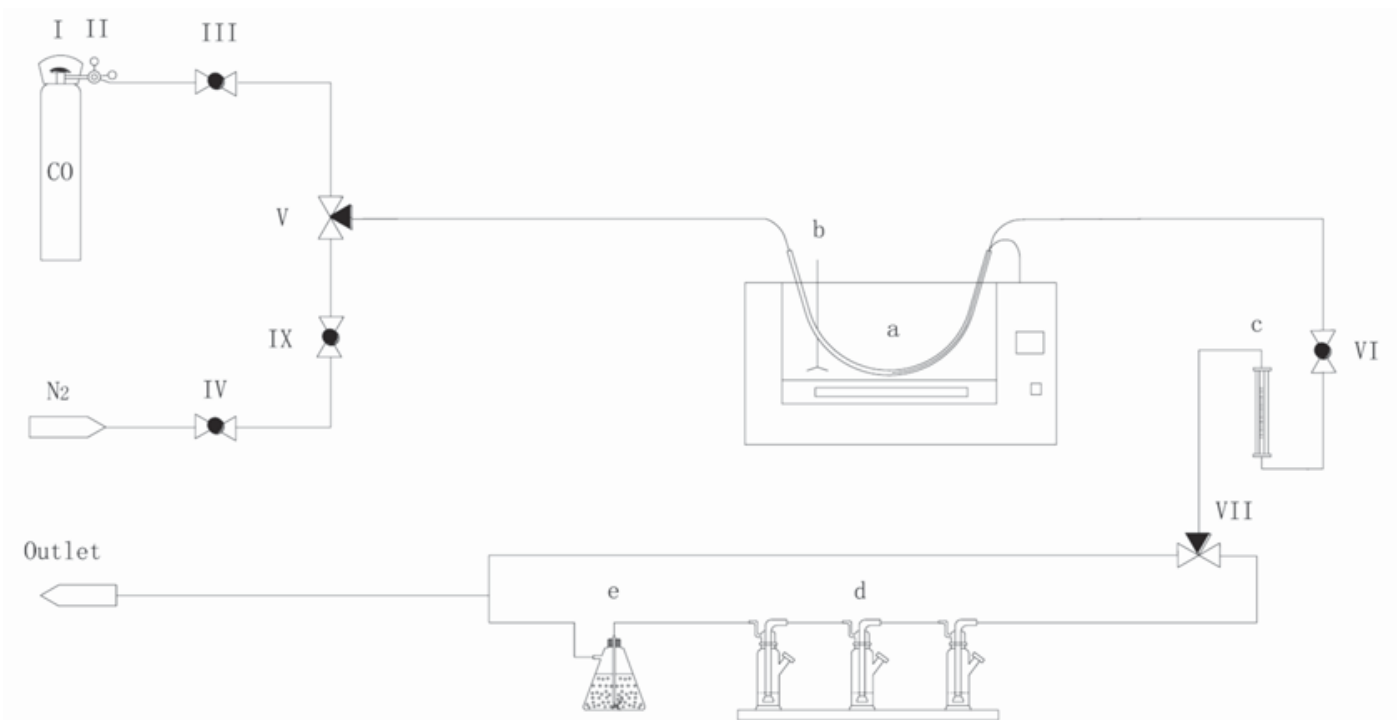

a: 0il Bath b: Stirrer c: Flow Meter d: Absorption Bottles e: Absorption bottle I VIII: Valves

I: C0 Gas Cylinder Valve II: C0 Gas Cylinder Valve Regulator III: Co Break Valve IV: N2 Break Valve

Figure 1-Schematic set-up for the carbonylation experiments
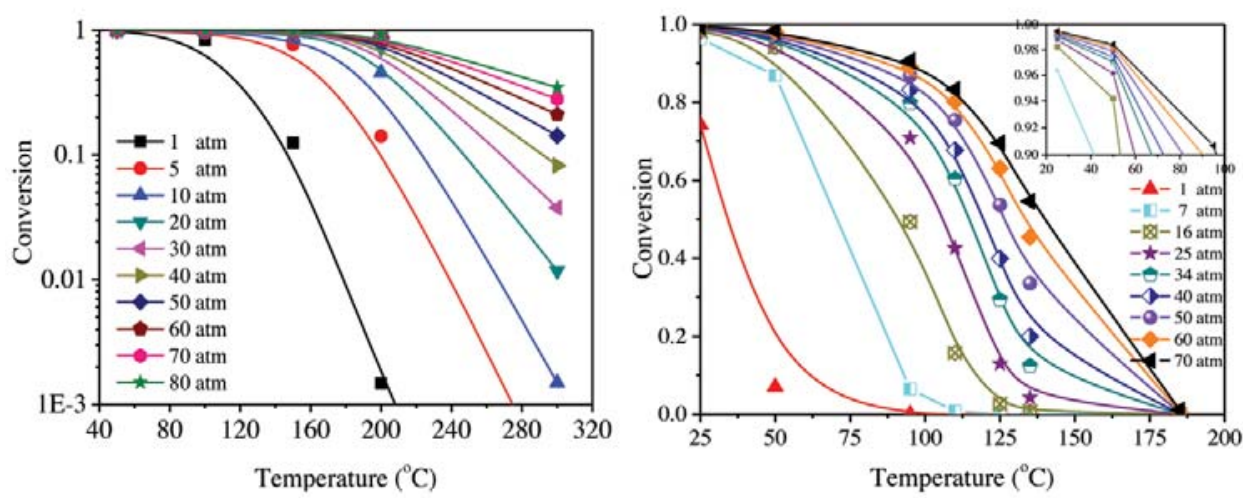

Figure 2-Calculated effect of temperature on conversion of $\mathrm{Ni}$ to $\mathrm{Ni}(\mathrm{CO})_{4}(\mathrm{left})$ and conversion of $\mathrm{Fe} \mathrm{to} \mathrm{Fe}(\mathrm{CO})_{5}$

experimental temperature, carbon monoxide was introduced into the reactor and the $\mathrm{CO}$ pressure was raised to the experimental value at a specific flow rate. During the experiment, samples were taken from the solutions in the Dreschel bottles at specified intervals and diluted to $10 \mathrm{ml}$ for analysis by ICP-OES. When the experiment was finished, the CO gas was switched off, and the system was purged with hydrogen for 20 minutes at a flow rate of $1 \mathrm{~L} \mathrm{~min}^{-1}$ at atmospheric pressure to remove residue $\mathrm{CO}$ and carbonyls. The aqua regia in the Dreschel bottles was diluted with deionized water to $1000 \pm 2 \mathrm{~mL}$ and analysed by ICP-OES.

The extent of nickel and iron carbonylation $(y)$ was calculated from the concentration of the metals in the absorbent:

$$
y=\frac{\text { mass of converted metal }}{\text { initial mass of metal }} * 100
$$

\section{Thermodynamic analysis}

Carbonylation of nickel and iron can be represented by
Equations [1] and [2]:

$$
\begin{gathered}
\mathrm{Ni}_{(s)}+4 \mathrm{CO}_{(g)}=\mathrm{Ni}(\mathrm{CO})_{4(g)} \\
\mathrm{Fe}_{(s)}+5 \mathrm{CO} \mathrm{O}_{(g)}=\mathrm{Fe}(\mathrm{CO})_{5(g)}
\end{gathered}
$$

Equilibrium constants for the reactions are (Ross, Haynie, and Hochman, 1964):

$$
\begin{aligned}
& \log K(N i)=8546 / T-21.64 \\
& \log K(F e)=8940 / T-30.0
\end{aligned}
$$

where $T$ is the temperature in kelvin.

The calculated effect of temperature on carbonylation of nickel and iron at CO pressures 1-80 atm. is shown in Figure 2.

At equilibrium, the conversion of both $\mathrm{Ni}$ and $\mathrm{Fe}$ to carbonyls increases with decreasing temperature and increasing $\mathrm{CO}$ pressure. Conversion of $\mathrm{Ni}$ to $\mathrm{Ni}(\mathrm{CO})_{4}$ at 


\section{Carbonylation of nickel and selectively reduced laterite ore}
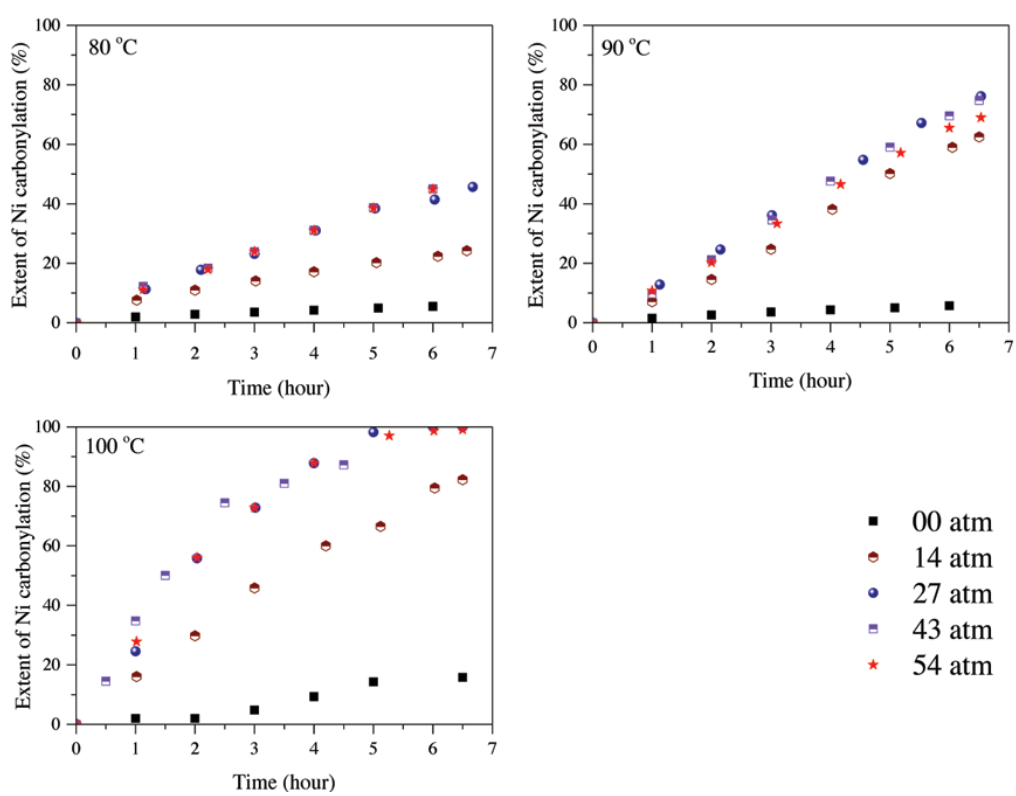

- 00 atm

- 14 atm

- $27 \mathrm{~atm}$

$=43 \mathrm{~atm}$

* 54 atm

Figure 3-Measured carbonylation of nickel at 80,90 , and $100^{\circ} \mathrm{C}$ and $\mathrm{CO}$ gauge pressure $0-54$ atm
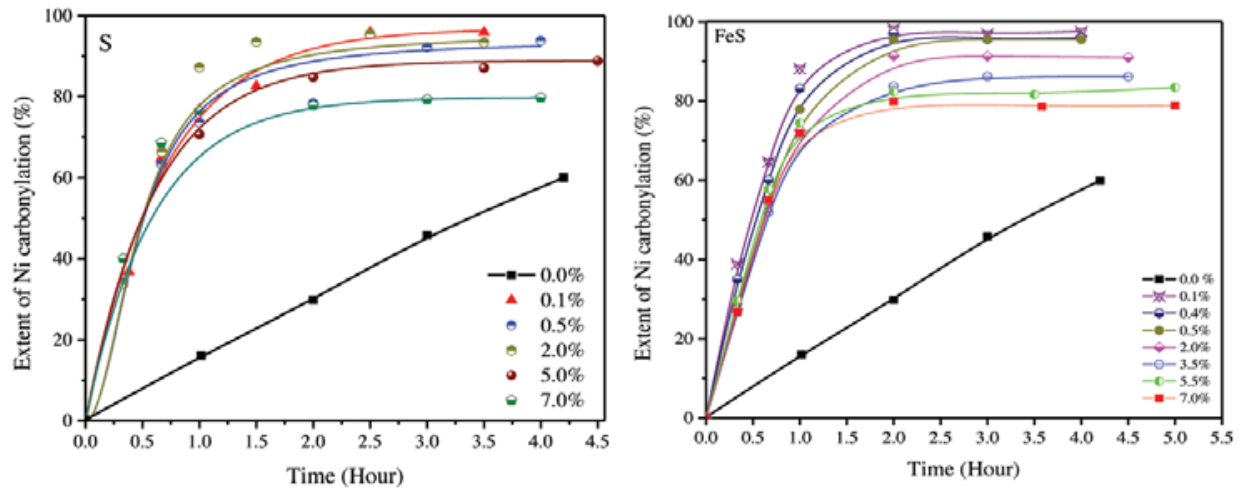

Figure 4-Catalytic carbonylation of nickel at $100^{\circ} \mathrm{C}$ and $\mathrm{CO}$ pressure $14 \mathrm{~atm}$. with addition of $\mathrm{S}$ and $\mathrm{FeS}$

temperatures below $100^{\circ} \mathrm{C}$ under $\mathrm{CO}$ pressure below $20 \mathrm{~atm}$. is above $95 \%$. Conversion of iron under the same conditions is much lower, less than $50 \%$ at $100^{\circ} \mathrm{C}$ under CO pressure of $20 \mathrm{~atm}$. Thermodynamic analysis shows that a high extent of nickel carbonylation can be achieved at temperatures below $100^{\circ} \mathrm{C}$ and CO pressure above $20 \mathrm{~atm}$. Carbonylation of iron at $100^{\circ} \mathrm{C}$ requires higher pressure, above $30 \mathrm{~atm}$.

\section{Experimental results}

\section{Non-catalytic carbonylation of pure nickel}

Nickel was obtained by reduction of $\mathrm{NiO}$ ( $99 \%$, the main impurity was $\mathrm{SiO}_{2}$ ) by hydrogen at $500^{\circ} \mathrm{C}$. The particle size of the NiO was less than $45 \mu \mathrm{m}$. Non-catalytic carbonylation of pure nickel was studied at $80-100^{\circ} \mathrm{C}$ and $\mathrm{CO}$ pressures of $1-$ $55 \mathrm{~atm}$. The gas flow rate in the carbonylation experiments was $0.5 \mathrm{~L} \mathrm{~min}^{-1}$. Figure 3 presents the extent of $\mathrm{Ni}$ carbonylation as a function of the reaction time at 80,90 , and $100^{\circ} \mathrm{C}$ and $\mathrm{CO}$ gauge pressures $0,14,27,43$, and 54 atm.

The carbonylation rate increased with increasing temperature; the degree of carbonylation after 5 hours' reaction reached over $99 \%$ at CO gauge pressure 27 atm. when the temperature increased to $100^{\circ} \mathrm{C}$. The carbonylation rate also increased with increasing $\mathrm{CO}$ gauge pressure from 0 to $27 \mathrm{~atm}$; a further increase in CO pressure had only a minor effect on the rate of reaction.

The rate of Ni carbonylation decreased with increasing particle size (in the range $0.3-2.7 \mu \mathrm{m}$ ); the effect of the particle size was strong when the mean particle size was above $1.1 \mu \mathrm{m}$.

The effect of gas flow rate on Ni carbonylation was examined in the range $0.14-0.5 \mathrm{~L} \mathrm{~min}^{-1}$ at $100^{\circ} \mathrm{C}$ and $\mathrm{CO}$ gauge pressure $27 \mathrm{~atm}$. An increased gas flow rate increased the rate of Ni carbonylation. 


\section{Carbonylation of nickel and selectively reduced laterite ore}

\section{Catalytic carbonylation of nickel}

Catalytic carbonylation of Ni was studied using sulphur and iron sulphide. In these experiments, nickel (about $1.3 \mathrm{~g}$ ) was mixed with a catalyst (0.1-0.7 wt\%) before carbonylation. Carbonylation curves obtained in experiments with different contents of sulphur are shown in Figure 4. Sulphurcontaining catalysts greatly accelerated the carbonylation reaction. The addition of $0.1 \mathrm{wt} \% \mathrm{~S}$ shortened the reaction time for $60 \%$ carbonylation from 4.2 hours in the noncatalytic carbonylation to less than 40 minutes in the catalytic reaction. The catalytic effects of sulphur and iron sulphide were very similar. However, increasing the catalyst content from 0.1 to $7.0 \mathrm{wt} \% \mathrm{~S}$ resulted in a decrease in the extent of nickel carbonylation, from above $90 \%$ to $80 \%$.
In the study of the effects of other parameters on the catalytic carbonylation of nickel, $0.1 \mathrm{wt} \%$ sulphur in the form of FeS was added to the nickel.

The effect of temperature on the catalytic carbonylation of nickel was examined in the range of $80-100^{\circ} \mathrm{C}$ at a $\mathrm{CO}$ pressure of $14 \mathrm{~atm}$. with a gas flow rate of $0.5 \mathrm{~L} \mathrm{~min}^{-1}$. The sample $(1.3 \mathrm{~g})$ contained $0.1 \mathrm{wt} \%$ sulphur in the form of FeS. Carbonylation curves obtained in experiments at 80,90 and $100^{\circ} \mathrm{C}$ are shown in Figure 5 . The carbonylation rate increased with increasing temperature from 80 to $90^{\circ} \mathrm{C}$, but a further increase in temperature from 90 to $100^{\circ} \mathrm{C}$ had only a minor effect on the reaction rate.

The effect of $\mathrm{CO}$ pressure on the catalytic carbonylation of nickel was studied at $100^{\circ} \mathrm{C}$ and $\mathrm{CO}$ pressures of 14 and
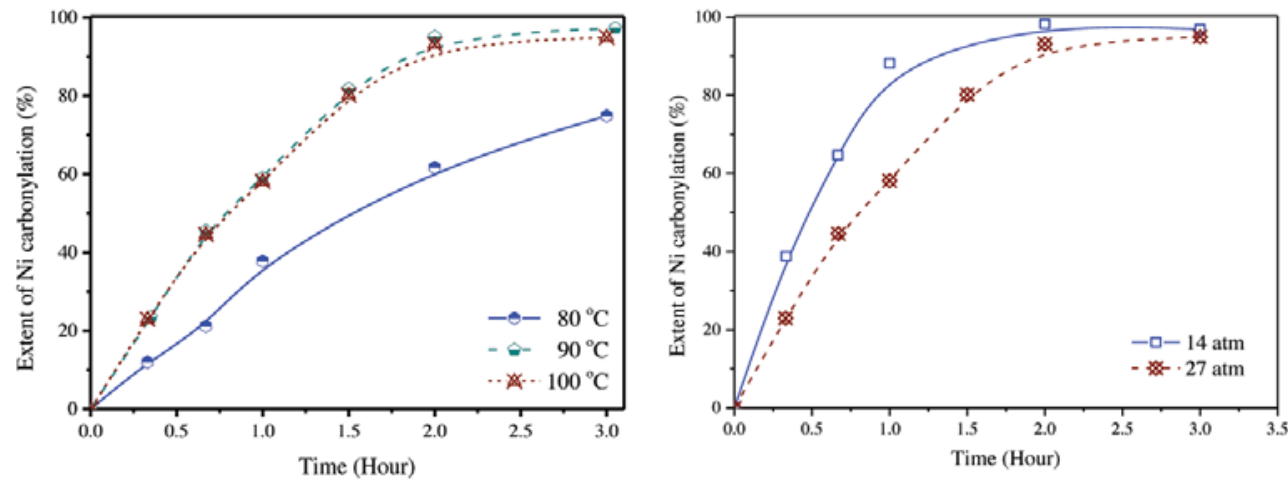

Figure 5-Effects of temperature (at $\mathrm{CO}$ gauge pressure $14 \mathrm{~atm}$.) and $\mathrm{CO}$ gauge pressure (at $100^{\circ} \mathrm{C}$ ) on the catalytic carbonylation of nickel
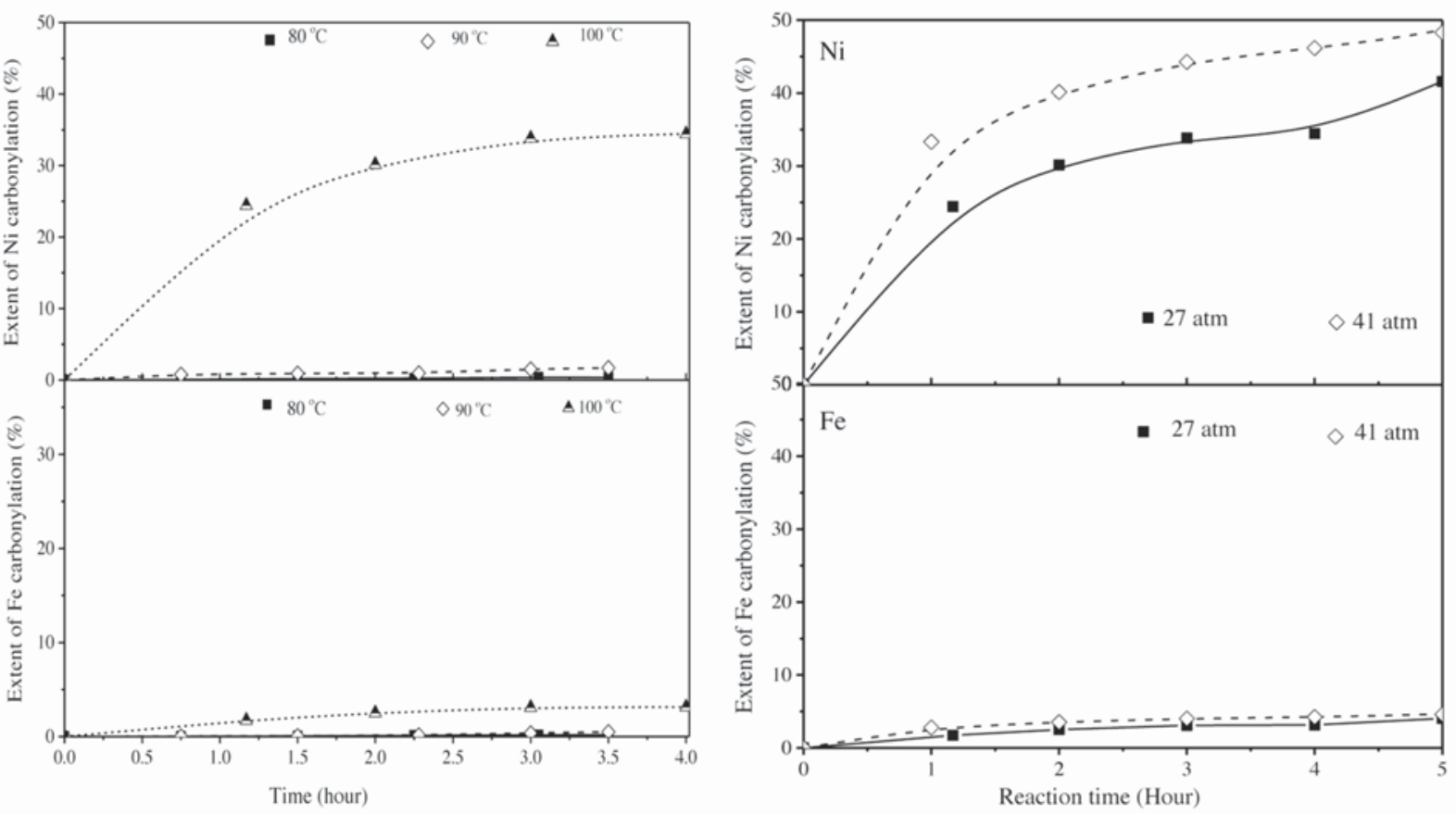

Figure 6-Effect of temperature on the non-catalytic carbonylation of nickel and iron from selectively reduced laterite ore at $\mathrm{CO}$ gauge pressure 27 atm., and effect of $\mathrm{CO}$ pressure at $100^{\circ} \mathrm{C}$ 


\section{Carbonylation of nickel and selectively reduced laterite ore}

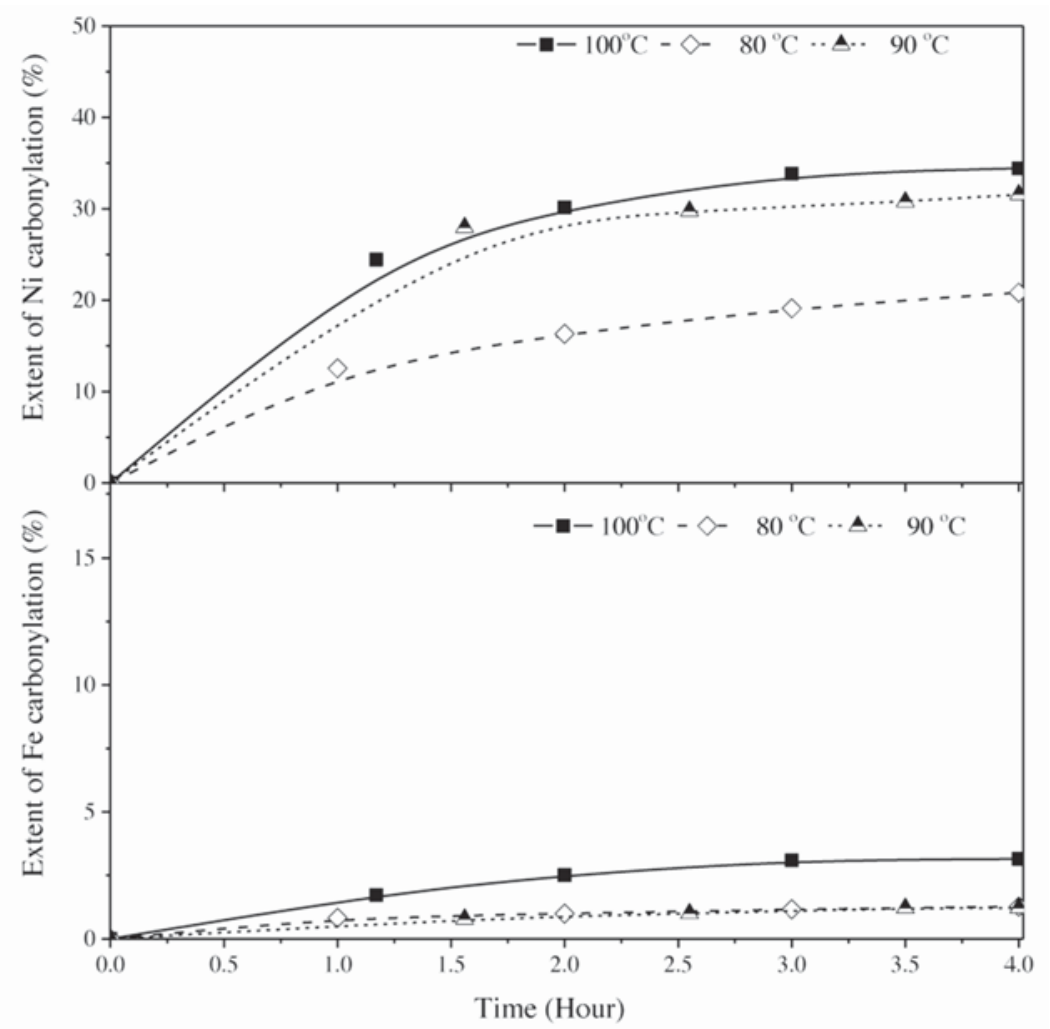

Figure 7-Catalytic carbonylation of nickel and iron from the selectively reduced laterite ore at 80,90 and $100^{\circ} \mathrm{C}$; $\mathrm{CO}$ gauge pressure 27 atm

$27 \mathrm{~atm}$. (Figure 5). The rate of carbonylation at $27 \mathrm{~atm}$. CO pressure was lower than at $14 \mathrm{~atm}$. in the first two hours of reaction. The extents of nickel carbonylation after 3 hours' reaction at both CO pressures were very close; $97 \%$ at a CO gauge pressure of $14 \mathrm{~atm}$. and $95 \%$ at $27 \mathrm{~atm}$.

\section{Carbonylation of selectively reduced laterite ores}

Garnierite laterite nickel ore containing $1.66 \% \mathrm{Ni}, 11.7 \mathrm{Fe}$, and 0.045 Co (by mass) with a particle size $<53 \mu \mathrm{m}$ was reduced in a $\mathrm{CO}-\mathrm{CO}_{2}$ gas mixture containing 60 vol. $\% \mathrm{CO}$ at $750^{\circ} \mathrm{C}$. The extents of reduction of nickel, cobalt, and iron oxides from the ore reached 91,85 , and $19 \%$ respectively. $\mathrm{Ni}$, $\mathrm{Co}$, and Fe oxides were reduced to the ferroalloy in the form of fine (sub-micrometre) particles which were homogeneously distributed in a silicate matrix.

\section{Non-catalytic carbonylation}

The effect of temperature on the non-catalytic carbonylation of selectively reduced laterite ore was studied using a sample mass of $1.5 \mathrm{~g}$ at 80,90 and $100^{\circ} \mathrm{C}$ under $\mathrm{CO}$ gauge pressure $27 \mathrm{~atm}$. The results are shown in Figure 6. Carbonylation of both nickel and iron at 80 and $90^{\circ} \mathrm{C}$ was very slow, but the reaction rate increased significantly when the temperature was increased to $100^{\circ} \mathrm{C}$. The extent of nickel carbonylation at $100^{\circ} \mathrm{C}$ after 3.5 hours' reaction reached $34 \%$, while the extent of iron carbonylation was only $3.1 \%$.

Increasing the CO gauge pressure from 27 to $41 \mathrm{~atm}$. increased the rate of carbonylation of nickel in the first hour of reaction but had no discernible effect on the carbonylation of iron. The extent of $\mathrm{Ni}$ carbonylation at $100^{\circ} \mathrm{C}$ and $\mathrm{CO}$ gauge pressure $41 \mathrm{~atm}$. after 5 hours' reaction was close to $50 \%$.

Catalytic carbonylation of selectively reduced laterite ore Catalytic carbonylation of selectively reduced laterite ore was studied using hydrogen sulphide $\left(\mathrm{H}_{2} \mathrm{~S}\right)$, which was introduced to the system with carbon monoxide at a concentration of 1.0 vol.\%.

Carbonylation curves for nickel and iron at 80, 90, and $100^{\circ} \mathrm{C}$ are plotted in Figure 7 . Increasing the temperature from 80 to $90^{\circ} \mathrm{C}$ increased the rate of carbonylation of nickel but had no effect on the carbonylation of iron. A further increase in temperature to $100^{\circ} \mathrm{C}$ led to a marginal increase in the extent of carbonylation of nickel (less than 2\% after 4.5 hours' reaction), and increased the rate of iron carbonylation, although the extent of iron carbonylation at $100^{\circ} \mathrm{C}$ after 4 hours' reaction remained low, less than $3 \%$.

\section{Discussion}

The carbonylation process proceeds by external and internal mass transfer of gaseous $\mathrm{CO}$ and $\mathrm{Ni}(\mathrm{CO})_{4}$, adsorption of $\mathrm{CO}$ on the Ni particles, and the formation and desorption of $\mathrm{Ni}(\mathrm{CO})_{4}$.

Thermodynamic analysis shows that the carbonylation reaction is favoured by lower temperatures (Figure 2). The strong positive effect of increased temperature on the $\mathrm{Ni}$ carbonylation indicates that the kinetic factor dominates the thermodynamic factor; it also indicates that the chemical 


\section{Carbonylation of nickel and selectively reduced laterite ore}

reaction contributed to the rate-controlling steps in the carbonylation reaction.

Nickel carbonylation by reaction [1] proceeds through the formation of intermediate species (Redmon, 1980):

$$
\mathrm{Ni}+\mathrm{CO} \rightarrow \mathrm{NiCO}
$$

$$
\mathrm{NiCO}+3 \mathrm{CO} \rightarrow \mathrm{Ni}(\mathrm{CO})_{4}
$$

The formation of intermediate NiCO requires a large activation energy and can be the slowest step in the chemical reaction (Redmon, 1980).

The rate of the non-catalytic carbonylation of Ni can be presented as (for the first-order irreversible reaction):

$$
R=S k P_{C O}
$$

where $S$ is the interfacial gas-solid area, $k$ is the reaction rate constant, and $P_{\mathrm{CO}}$ is the CO pressure at the gas-solid interface.

The rate constant as a function of temperature is described by the Arrhenius equation:

$$
k=A e^{-\frac{E a}{R T}}
$$

where $A$ is a frequency factor or pre-exponential factor, $E_{a}$ is the activation energy $\left(\mathrm{J} \mathrm{mol}^{-1}\right), R$ is the gas constant (J.mol-1. $\mathrm{K}^{-1}$ ), and $T$ is temperature (K).

The activation energy determined from the experimental data at temperatures between from 80 and $100^{\circ} \mathrm{C}$ and $\mathrm{CO}$ gauge pressure $54 \mathrm{~atm}$. was found to be $114 \mathrm{~kJ} \cdot \mathrm{mol}-1$; this is in a reasonable agreement with the activation energy of 127 $\mathrm{kJ} \mathrm{mol}-1$ theoretically estimated by Redmon (1980). It follows from Equations [7] and [8] that the rate of the chemical reaction increases with increasing temperature and $\mathrm{CO}$ pressure, which was observed experimentally.

Mass transfer of $\mathrm{CO}$ and $\mathrm{Ni}(\mathrm{CO})_{4}$ in the gas phase also contributed to the rate-limiting factors as the rate of $\mathrm{Ni}$ carbonylation increased with increasing $\mathrm{CO}$ flow rate. It should be noted that increasing the $\mathrm{CO}$ pressure at a constant gas flow rate decreases the gas velocity in the reactor. Therefore, in the non-catalytic carbonylation of $\mathrm{Ni}$ and laterite ore, the positive effect of $\mathrm{CO}$ pressure on the rate of chemical reaction dominated over the negative effect on the mass transfer in the gas phase.

The use of sulphur catalysts changes the reaction mechanism; carbonylation proceeds through the formation of nickel sulphide $\left(\mathrm{Ni}_{3} \mathrm{~S}_{2}\right)$ which is converted to $\mathrm{Ni}(\mathrm{CO})_{4}$. The rate of chemical reaction in the catalytic carbonylation of nickel is much higher than in non-catalytic carbonylation. An increase in temperature from 90 to $100^{\circ} \mathrm{C} \mathrm{had} \mathrm{a} \mathrm{minor} \mathrm{effect}$ on the rate of catalytic carbonylation. This indicates that the chemical reaction did not contribute to the rate control of catalytic carbonylation at $90-100^{\circ} \mathrm{C}$; mass transfer in the gas phase became the rate controlling stage. In this case, the increase in the CO pressure decreased the rate of carbonylation as it decreased the gas velocity in the reactor.

The nickel oxide used for the production of Ni contained a small amount of impurities; the reduction of $\mathrm{NiO}$ to $\mathrm{Ni}$ was
95-97\%. Impurities and NiO were not carbonylated under the experimental conditions used. Internal mass transfer through the residue of Ni carbonylation also contributed to the rate control, which was particularly significant in the carbonylation of selectively reduced laterite ore.

\section{Conclusions}

- The rates of non-catalytic carbonylation of both nickel and laterite ore increased with temperature and CO pressure, although in the case of laterite ore, an increase in temperature from 80 to $90^{\circ} \mathrm{C}$ had only a minor effect, while a further increase to $100^{\circ} \mathrm{C}$ significantly accelerated the rate of carbonylation.

- The non-catalytic carbonylation of $\mathrm{Ni}$ at $100^{\circ} \mathrm{C}$ and $\mathrm{CO}$ gauge pressure 43-54 atm. was close to completion after about 5 hours' reaction; it was far from completion at 80 and $90^{\circ} \mathrm{C}$.

> Catalytic carbonylation of nickel and selectively reduced laterite ore exhibited a different behaviour to noncatalytic carbonylation. The rate of carbonylation of both $\mathrm{Ni}$ and laterite ore increased with increasing temperature from 80 to $90^{\circ} \mathrm{C}$, and was only slightly affected by a further increase in temperature to $100^{\circ} \mathrm{C}$. Increasing the $\mathrm{CO}$ gauge pressure decreased the rate of catalytic carbonylation of both $\mathrm{Ni}$ and laterite ore.

> The use of catalysts accelerated Ni carbonylation and had a marginal effect on the carbonylation of laterite ore.

> Carbonylation of iron from the selectively reduced laterite ore was slow; the extent of reaction was about $3 \%$ in both non-catalytic and catalytic carbonylation.

> The rate of non-catalytic carbonylation of $\mathrm{Ni}$ and laterite ore was controlled by the chemical reaction and external and internal mass transfer of gaseous $\mathrm{CO}$ and $\mathrm{Ni}(\mathrm{CO})_{4}$. Chemical reaction did not contribute to the rate of catalytic carbonylation at $90-100^{\circ} \mathrm{C}$.

\section{Acknowledgements}

This paper is based on the PhD thesis by Cui (2015). Financial support for this research was provided by the Australian Research Council (ARC Discovery Project DP1094880).

\section{References}

Cur, Y. 2015. Carbonylation of nickel and iron from reduced oxides and laterite ore. PhD thesis, University of New South Wales, Sydney.

Ross, L.W., Haynie, F.H., and Hochman, R.F. 1964. Thermodynamic functions of nickel carbonyl and iron pentacarbonyl. Journal of Chemical and Engineering Data, vol. 9, no. 3. pp. 339-340.

ReDmon, L.T. 1980. Final report on kinetics of $\mathrm{Ni}(\mathrm{CO})_{4}$ formation to U.S. Air Force Office of Scientific Research

http://www.dtic.mil/dtic/tr/fulltext/u2/a207136.pdf

TerekHov, D.S. and Emmanuel, N.V. 2013. Direct extraction of nickel and iron from latetrite ore using the carbonyl process. Minerals Engineering, vol 54. pp. 124-130.

VALE. 2017. Second quarter 2017 production report. http://www.vale.com/indonesia/EN/aboutvale/news/id/Pages/secondquarter-2017-production-report.aspx 